\section{Physical and mechanical properties of dolomites related to sedimentary and diagenetic features - case study of the Upper Triassic dolomites from the Medvednica and Samobor Mts., NW Croatia}

\author{
Ana Maričić́; Karlo Starčević; Uroš Barudžija ${ }^{3}$ \\ ${ }^{I}$ Faculty of Mining, Geology and Petroleum Engineering, University of Zagreb, Pierottijeva 6, Zagreb, Assistant Professor \\ ${ }^{2}$ Faculty of Mining, Geology and Petroleum Engineering, University of Zagreb, Pierottijeva 6, Zagreb, Master of Geology \\ ${ }^{3}$ Faculty of Mining, Geology and Petroleum Engineering, University of Zagreb, Pierottijeva 6, Zagreb, Assistant Professor
}

\begin{abstract}
Sedimentary and diagenetic features of Upper Triassic dolomites are determined and related to technical properties (apparent density, water absorption, open porosity and point load strength tested by Point Load Test, PLT) for possible use as building aggregate. Samples are taken from three quarries in the Medvednica and Samobor Mts., in NW Croatia. Samples from the Ivanec Quarry are determined as the early-diagenetic dolomite (EDD), late-diagenetic dolomite (LDD) and "transitional" dolomite (TD). Samples from the Dolje Quarry are determined as early-diagenetic dolomite (EDD) and late-diagenetic dolomite (LDD). The samples from the Gradna Quarry are determined as late-diagenetic dolomites (LDD). According to the physical and mechanical properties, the best variety to use as a crushed stone or as an aggregate proved to be the late-diagenetic dolomite from the Dolje Quarry. Samples from the Dolje Quarry have the lowest values of open porosity and water absorption and the highest values of apparent density and PLT, due to their sedimentary-diagenetic features.
\end{abstract}

Keywords:

dolomite, physical and mechanical properties, diagenesis, aggregates, Triassic, Croatia

\section{Introduction}

The aim of this paper is to describe sedimentary and diagenetic features of the Upper Triassic dolomites from the Medvednica and Samobor Mts. (NW Croatia) and to determine the relationship with their physical and mechanical properties. The case study is performed on several samples of dolomites, taken from the following quarries: the Dolje Quarry near Podsused, the Ivanec Quarry near Zaprešić and the Gradna Quarry near Samobor, all in the broad area of Zagreb, the capital of Croatia (see Figure 1). Physical and mechanical properties of the dolomites which have been analyzed and compared, are the following: apparent density, open porosity (HRN EN 1936), water absorption (HRN EN 13755) and point load strength by Point Load Test (ISRM, 1985).

Crushed stone is a natural raw-material, whose mineralogical and petrographic composition and physical-mechanical properties comply the technical requirements for civil constructions (Smith and Collis, 2001). Sedimentary-diagenetic features and physical-mechanical properties of sedimentary rocks are closely related. Testing and comparing of these properties have been highlighted by several authors, who state that besides many

Corresponding author: Ana Maričić

e-mail address: ana.maricic@rgn.hr other properties, lamination could strongly affect the physical-mechanical properties of the stone varieties (Tomašić et al., 1990, 1992, 1997, 2011; Tišljar et al. 1997; Tomašić and Ženko, 1993; Fort et al., 2002; Garcia Del Cura et al., 2005, Barudžija et al., 2015). The dolomitization affects the stone porosity and could increase the intergranular porosity in original carbonate rocks (Chilingar et al., 1979; Morse and Mackenzie, 1990; Morse, 2005). The distinction between the earlydiagenetic and late-diagenetic dolomites in the crystal sizes and ordering of the crystal lattices was already reported by Goldsmith and Graff (1958), and general classification to early- and late-diagenetic dolomites, together with their counterparts (primary-sinsedimentary and secondary dolomites), is widely used since then (Zenger et al., 1980; Tucker, 1990; Purser et al., 1994; Scholle and Ulmer-Scholle, 2003; Flügel, 2004). Early-diagenetic dolomites mainly have finer crystals and a high-ordered crystal lattice, and late-diagenetic dolomites mainly have large crystals and a low-ordered crystal lattice (Kaczmarek and Sibley, 2011). Dolomites often include relics of the sedimentary features, i.e. lamination, intraclasts, fenestrae and desiccation cracks, among others. These features often influence anisotropy, which significantly affects the physical and mechanical properties of the dolomites. 


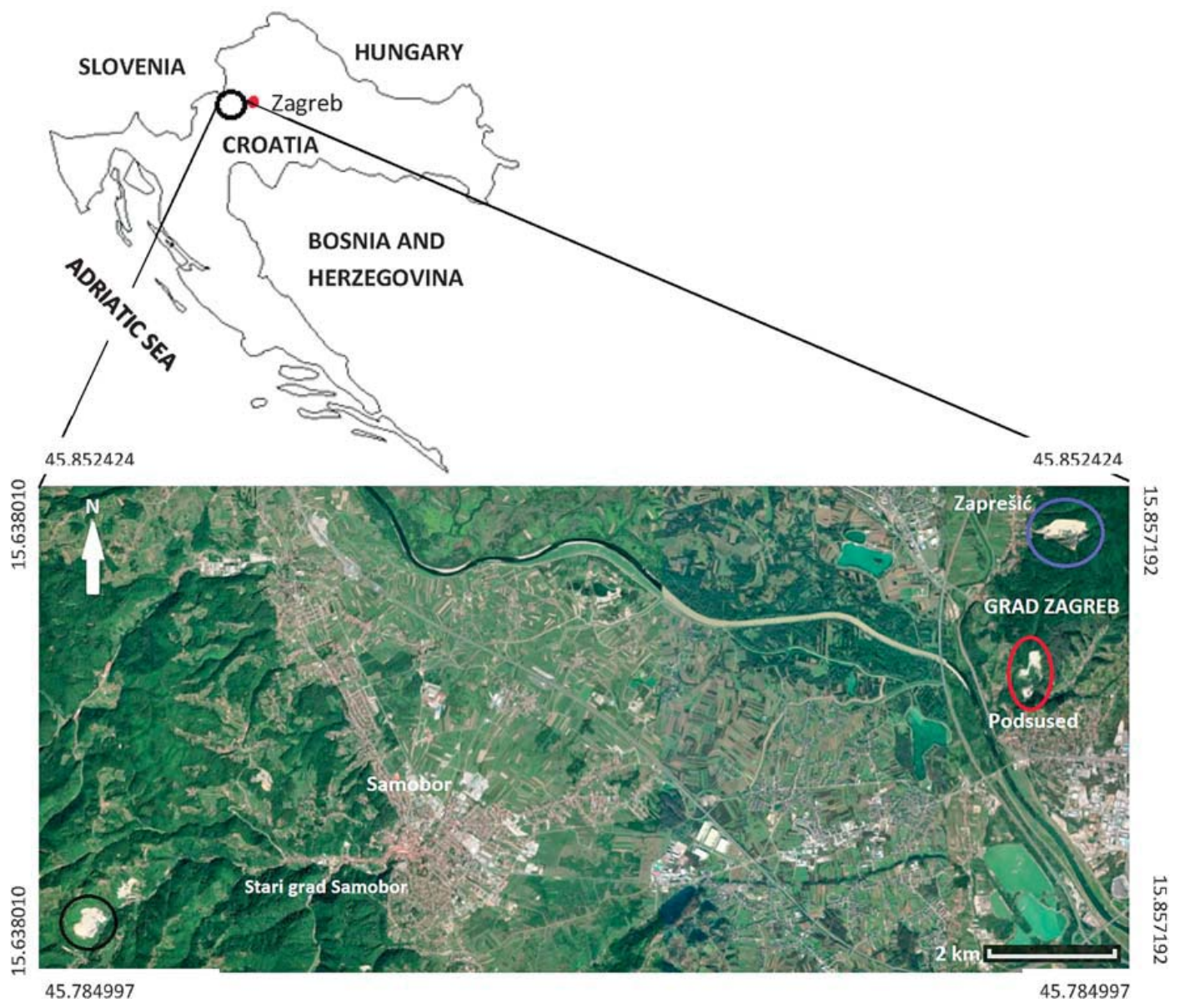

Figure 1: Geographical position of the investigated quarries: the Dolje Quarry (red), the Ivanec Quarry (blue) and the Gradna Quarry (black) (https://www.google.hr/maps/)

\section{Overview of geology in the investigated area}

Stratigraphy of the Triassic deposits in the SW Medvednica, Samobor Mts. and in the neighbouring Žumberak area, is well described and defined by Šikić and Basch (1975), Šikić et al. (1977, 1979), Fuček et al. (1995), Bukovac et al. (1995), Grgasović (1997, 1998), Avanić et al. (2000) and Herak (2006). Dolomites prevail throughout the Triassic successions and they are almost exclusively Upper Triassic sedimentary rock. Detailed litostratigraphic and biostratigraphic subdivision of the Upper Triassic deposits of the investigated area was published by Grgasović (1998). Dolomites described in this paper belong to the Upper Triassic (Norian-Retian) and litostratigraphically represent the Main Dolomite Formation, as described by Grgasović (1998), similar to the same lithological type of deposits in the neighbouring areas in Croatia, Slovenia, Italy and Austria (described by: Gušić et al., 1965; Bosellini, 1965, 1967; Babić, 1968; Herak, 1968; Müller-Jungbluth, 1968, 1970; Fruth and Scherreiks 1975, 1982, 1984; Velić and Sokač, 1982; Jadoul, 1986; Cirilli and Tan- noia, 1988; Bosellini and Hardie, 1988; De Zanche, 1990; Tišljar et al., 1991; Jadoul and Gnaccolini, 1991; Jadoul et al., 1992; Ogorelec and Rothe, 1993; Barattolo and Bigozzi, 1996; Satterley, 1996; Climaco et al., 1997).

\subsection{Geology of the Dolje Quarry}

The Dolje Quarry is situated within the Upper Triassic dolomites, on the SW slope of Medvednica Mt. Dolomites were exploited in the quarry, which is now abandoned, for crushed stone aggregates. Beds are dipping towards the South and partly tectonically disturbed. Overall thickness of the exposed succession in in the quarry is approximately $200 \mathrm{~m}$, of which $94 \mathrm{~m}$ is undisturbed, as reported by Fuček et al. (1995).

Dolomite succession is represented by shallowingupward cycles containing: (I) dark subtidal cryptocrystalline-to-microcrystalline dolomicritic members, occasionally with Megalodon shell molds (A member); (II) white intertidal laminated stromatolitic dolomite members (B member); and (III) white fenestral stromatoliticto-fenestral dolomicritic members (C member), (Fuček 
et al., 1995). Fenestral fabric is more frequent in the upper parts of the B members, with characteristic vadosediagenetic features. Some cycles terminate with the erosional surfaces and these intervals contain peritidal carbonate breccias. Bed thicknesses are between 0.5 and $1.5 \mathrm{~m}$, and those of shallowing-upward cycles are between $45 \mathrm{~cm}$ and $4.5 \mathrm{~m}$ (Fuček et al., 1995).

\subsection{Geology of the Ivanec Quarry}

The Ivanec Quarry is situated on the NW slope of the Medvednica Mt. Succession is characterised by a vertical alternation of white and dark beds, with thicknesses from 0.5 to $1.5 \mathrm{~m}$. Sediment is tectonically disturbed, and mostly overturned. Similar to the above described dolomites from the Dolje Quarry, dolomites represent shallowing-upward cycles: dark subtidal cryptocrystalline-to-microcrystalline dolomicritic members (A member), white intertidal laminated stromatolitic members (B member), and white fenestral stromatolitic-to-fenestral dolomicritic white members (C member) (Fuček et al., 1995).

\subsection{Geology of the Gradna Quarry}

The Gradna Quarry is located in the Samobor Mt. Dolomites in the Gradna Quarry are heavily tectonically disturbed with almost completely obliterated bedding. Most probably post-diagenetic processes resulted in the increasing firmness of the rocks in the SW part of the quarry (Tomašić and Peh, 1992).

\section{Methodology}

During fieldwork sampling for the later laboratory analysis of dolomites was done in all three quarries. In the laboratory, micropetrographical analysis and determination of physical-mechanical properties were done on the collected samples.

\subsection{Micropetrographical analysis}

Macroscopic determination of sedimentary features is made on the polished slabs perpendicular to the bedding (see Figure 2). Micropetrographic analysis is performed by petrographic microscope Leica DM LSP, equipped with a digital camera. All thin-sections are stained with Alizarin red S and K-Ferricyanide (according to the procedure proposed by Evamy and Shearman, 1962), in order to distinguish carbonate mineral species present within. Dolomites were described according to the size and shape of their crystals and according to the dolomitic fabric, as proposed by Sibley and Gregg (1987), in order to compare these characteristics with the analysed physical-mechanical properties. Furthermore, characteristics of preserved original sedimentary features were also observed. For the purpose of this study and distinct comparison of their properties, dolomites

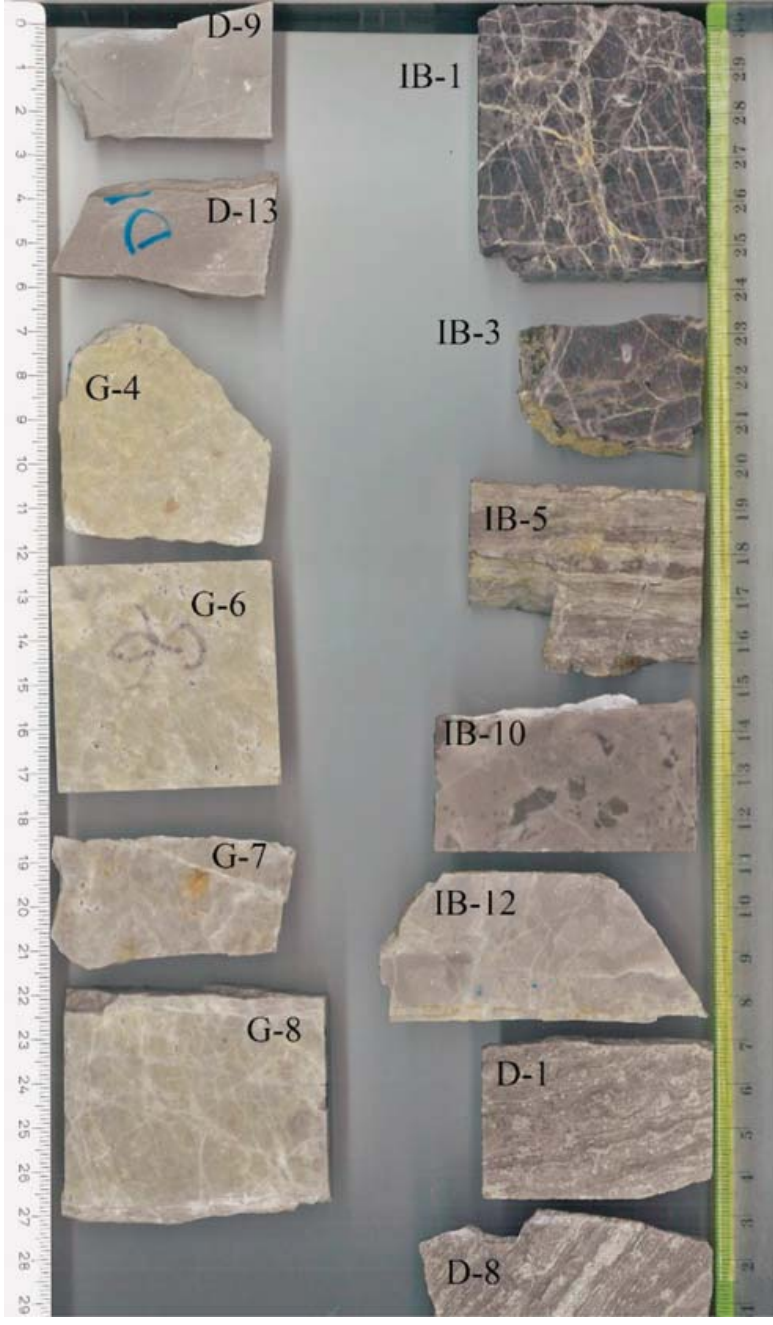

Figure 2: Polished slabs of the dolomite samples, taken for the macroscopic determination of their sedimentary and diagenetic features (markings on the samples:

D- Dolje Quarry, G- Gradna Quarry, IB- Ivanec Quarry)

were conventionally named as early-diagenetic (ED) dolomites (B and C members of Fuček et al., 1995, in Dolje and Ivanec) and late-diagenetic (LD) dolomites (A member of Fuček et al., 1995 in Dolje and Ivanec). An additional term, "transitional" dolomite (TD), is also introduced for dolomites having the structural features of both ED and LD dolomites.

\subsection{Testing of physical and mechanical properties}

The basic physical and mechanical properties (apparent density, open porosity, water absorption and point load strength by Point Load Test - PLT) were determined on 26 samples (13 samples from the Ivanec, 9 samples from the Dolje and 4 samples from the Gradna quarries), which enabled mutual correlation of values. Testing included different numbers of samples of each of the dolomites due to a large number of cracks in the samples which caused crushing during the cutting and prep- 
aration of the samples into the shape of cubes for analysis. Testing was done in the Geomechanics Laboratory (PLT) and in the Laboratory for Analysis of Geological Materials, both at the Faculty of Mining, Geology and Petroleum Engineering, University of Zagreb.

For determination of apparent density $\left(\rho_{b}\right)$ and open porosity $\left(p_{o}\right)$, samples were subjected to water absorption $\left(A_{b}\right)$, according to the HRN EN 1936 standard. The samples were first weighed in a dry state $\left(m_{d}\right)$. Afterwards, samples were gradually immersed in water. The weight of saturated samples $\left(m_{s}\right)$ and the weight of the samples immersed in water $\left(m_{h}\right)$ were measured.

Apparent density $\left(\rho_{b}\right.$ in $\left.\mathrm{g} / \mathrm{cm}^{3}\right)$ is expressed as the ratio of the mass of the dry sample and its apparent volume by the Equation 1:

$$
\rho_{b}=\frac{m_{d}}{m_{s}-m_{h}} * \rho_{r h}
$$

Where:

$\rho_{b}$ - apparent density $\left(\mathrm{g} / \mathrm{cm}^{3}\right)$;

$m_{s}$ - mass of the saturated sample $(\mathrm{g})$;

$m_{d}$ - mass of dry sample $(\mathrm{g})$;

$m_{h}$ - mass of immersed sample in water $(\mathrm{g})$;

$\rho_{r h}$ - density of water $\left(\mathrm{g} / \mathrm{cm}^{3}\right)$.

Open porosity ( $p_{o}$ in vol. $\%$ ) are all interconnected pores that can be filled with water at the atmospheric pressure. It represents the ratio between the volume of the open pores and the apparent volume of the specimen, and it is calculated by the Equation 2:

$$
p_{o}=\frac{m_{s}-m_{d}}{m_{s}-m_{h}} * 100
$$

Where:

$$
\begin{aligned}
& p_{o}-\text { open porosity }(\text { vol. } \%) ; \\
& m_{s}-\text { mass of the saturated sample }(\mathrm{g}) ; \\
& m_{d}-\text { mass of dry sample }(\mathrm{g}) ; \\
& m_{h}-\text { mass of immersed sample in water }(\mathrm{g}) .
\end{aligned}
$$

During the testing of water absorption according to HRN EN 13755, the cubic samples $(5 \mathrm{~cm}$ x $5 \mathrm{~cm} \times 5 \mathrm{~cm}$ ) were gradually immersed in water. The sample masses were measured every 24 hours until samples reached complete saturation, i.e. until the mass of the sample was of constant weight. The samples were subjected to water absorption during a period of 7 days. During the testing, the mass was measured within time intervals (30 $\mathrm{min}, 1$ h, 2 h, 3 h, 24 h, 48 h, 72 h, 96 h and 168 h). Water absorption $\left(A_{b}\right.$ in mass. \%) at atmospheric pressure is expressed by the Equation 3:

$$
A_{b}=\frac{m_{s}-m_{d}}{m_{d}} * 100
$$

Where:

$$
\begin{aligned}
& A_{b}- \text { water absorption at atmospheric pressure } \\
&(\text { mass. \%); } \\
& m_{s}- \text { mass of the saturated sample }(\mathrm{g}) ; \\
& m_{d}-\text { mass of dry sample }(\mathrm{g}) ; \\
& m_{h}-\text { mass of immersed sample in water }(\mathrm{g}) .
\end{aligned}
$$

Determination of the point load strength by Point Load Test - PLT (ISRM, 1985) was performed on cubic samples $(5 \mathrm{~cm} \times 5 \mathrm{~cm} \times 5 \mathrm{~cm})$. Determination of the point load strength is used to obtain the strength of the samples. Lamination in samples were oriented perpendicular to the direction of load. After the breakdown of a sample, the validity of the test, performed on the basis of the appearance of fractures, was done. It should be noted that during the testing, two samples out of four from the Gradna Quarry did not break regularly and were excluded from further calculation. The PLT load strength $\left(I_{S(50)}\right.$ in $\mathrm{MPa}$ ) for samples of different shapes and dimensions is calculated using the Equation 4:

$$
I_{s(50)}=F \frac{P}{D_{e}^{2}}
$$

Where:

$$
\begin{aligned}
& I_{s(50)}-\text { point load strength by PLT }(\mathrm{MPa}) \\
& F-\text { correction factor }(-) ; \\
& P \quad-\text { force }(\mathrm{N}) ; \\
& D_{e}-\text { effective diameter of the sample }(\mathrm{m}) .
\end{aligned}
$$

\section{Results}

In the Results section, analysis of thin-sections with physical-mechanical properties of the dolomites will be outlined.

\subsection{Analysis of thin-sections}

According to the macroscopic determination of the sedimentary and diagenetic features and micropetrographical analysis of the dolomite samples taken in Dolje (D- samples), Ivanec (IB- samples) and Gradna (G- samples) (see Figure 2), dolomites were determined. The dolomites determined in Dolje are early-diagenetic (EDD) and late-diagenetic (LDD). In Ivanec, the determined dolomites are early-diagenetic (EDD), late-diagenetic (LDD) and "transitional" dolomites (TD), while in Gradna, only late-diagenetic dolomite (LDD) was determined.

4.1.1. Dolje Quarry - early-diagenetic dolomite (EDD)

The early-diagenetic dolomites from Dolje are gray in colour and have a distinct stromatolitic lamination, as the major sedimentary-diagenetic feature observed (D-1 and D-8 in Figure 2). Dolomite crystals are anhedral to subhedral and their size ranges between $0.08 \mathrm{~mm}$ and $0.14 \mathrm{~mm}$. These unimodal (equigranular) crystals form the hypidiotopic mosaic fabric between micritie laminas (see Figure 3a). There are no major cracks, and microcracks are not preferentially oriented, but diverge in all directions.

\subsubsection{Dolje Quarry - late-diagenetic dolomite (LDD)}

The late-diagenetic dolomites (LDD) from Dolje are bright in colour, and they contain irregularly oriented cracks, as the distinct features of their structure (D-9 and 
D-13 in Figure 2). Dolomite crystal size ranges between $0.02 \mathrm{~mm}$ and $0.12 \mathrm{~mm}$, and this is mainly a fine-grained dolomite while larger dolomite crystals appear only within the microcracks (see Figure 3b). Grain boundaries among crystals are mainly undeterminable, while larger dolomite crystals within microcracks are subhedral. Red colouration indicates calcitization within microcracks.

4.1.3. Ivanec Quarry - early-diagenetic dolomite (EDD)

The early-diagenetic dolomites (EDD) from Ivanec have a stromatolite lamination and fenestral fabric, and the major features observed (IB-5 in Figure 2), are similar to those previously described EDD dolomite from Dolje. Fenestrae in their lower parts have a geopetal fill- ing composed of dolomite silt $(0.01 \mathrm{~mm})$, and larger (up to $0.1 \mathrm{~mm}$ ) dolomite crystals which make a mosaic in the upper originally empty parts of the fenestrae (see Figure 3c). These dolomites are often completely dark in colour, laminated, and have numerous randomly oriented cracks and microcracks (see IB-1 and IB-3 in Figure 2). Thick cracks are filled with clear, up to $1.2 \mathrm{~mm}$ large anhedral dolomite crystals, and subsequently with small calcite crystals, while microcracks are filled only with calcite.

\subsubsection{Ivanec Quarry - "transitional” dolomite (TD)}

The "transitional" dolomites (TD) from Ivanec are bright-gray in colour, laminated with rare fenestrae (IB10 in Figure 2). Dark parts of the sample are dolomicrite

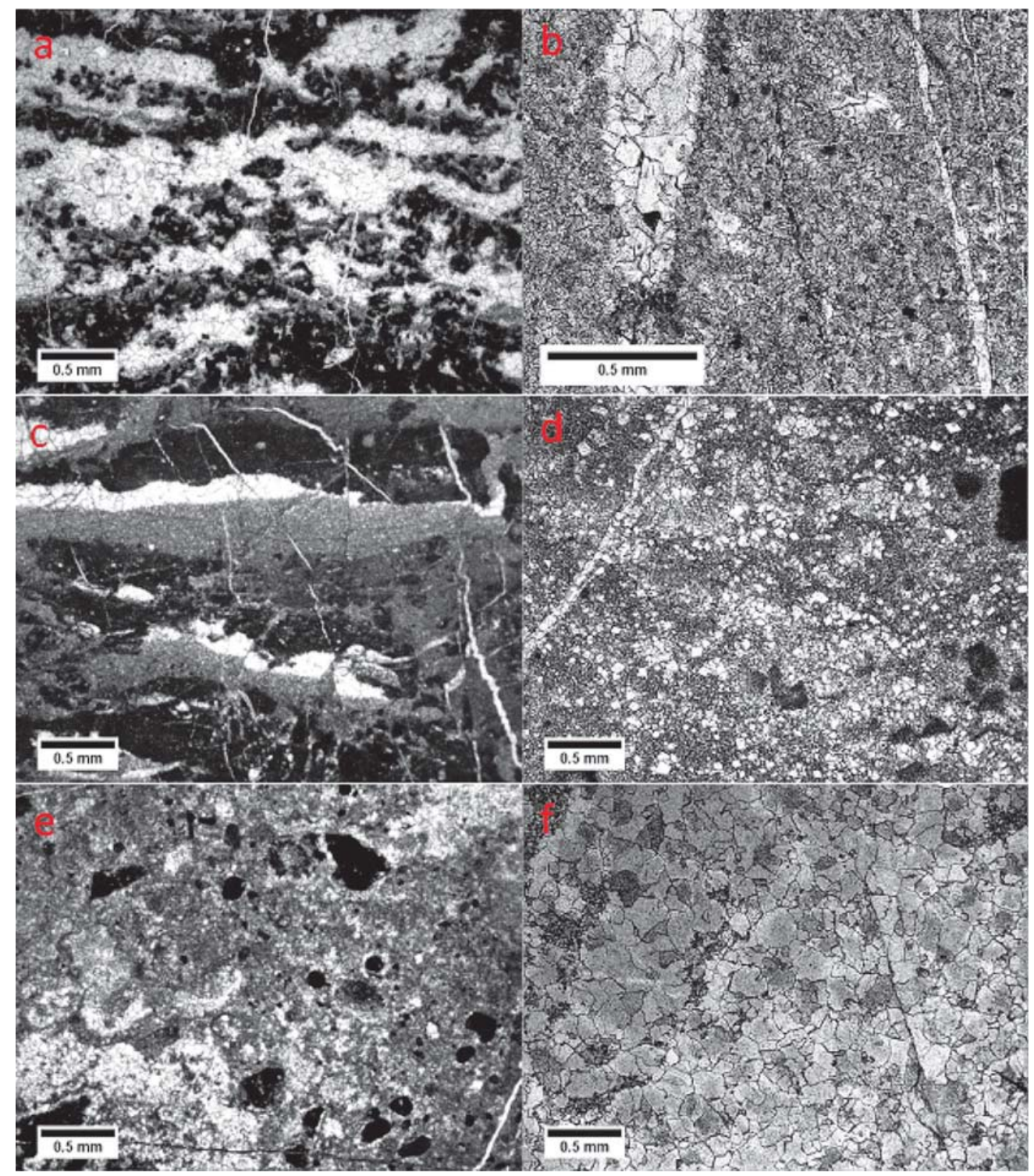

Figure 3: Microphotographs of the dolomites: a) D-8 early-diagenetic dolomite (EDD) from Dolje; b) D-9 late-diagenetic dolomite (LDD) from Dolje; c) IB-5 early-diagenetic dolomite (EDD) from Ivanec; d) IB-10 "transitional" dolomite (TD) from Ivanec; e) IB-12 late-diagenetic dolomite (LDD) from Ivanec; f) G-6 late-diagenetic dolomite (LDD) from Gradna. 
with organic matter (see Figure 3d). Lamination is clearly visible, as well as numerous microcracks which are mainly perpendicular to lamination. Most of the microcracks are empty, but some of them are filled with dolomite or calcite crystals. Fenestrae are filled with densely arranged, anhedral dolomite crystals (0.02 to $0.12 \mathrm{~mm}$ ). These polymodal (inequigranular) dolomite crystals form the porphyrotopic crystal mosaic fabric, with large dolomite crystals in a dolomicritic matrix.

4.1.5. Ivanec Quarry - late-diagenetic dolomite (LDD)

The late-diagenetic dolomites (LDD) from Ivanec are bright-gray in colour, and they contain small, randomlyoriented cracks (IB-12 in Figure 2). Dolomicrite prevails, and cracks filled with dolomite crystals (0.04 to 0.12) are also present. Apart from the cracks, clusters with clear dolomite crystals appear within prevailing dolomicrite. Red colouration, visible along the edges of the small microcracks, indicate calcitization. Dark clusters rich in the organic matter, are present within as well (see Figure 3e).

\subsubsection{Gradna Quarry - late-diagenetic dolomite (LDD)}

The late-diagenetic dolomites (LDD) from the Gradna Quarry are both bright and dark in colour (G-4, G-6, G-7 and G-8 in Figure 2). Dark varieties contain numerous, irregularly-oriented, cracks. The size of dolomite crystal ranges between 0.04 and $0.2 \mathrm{~mm}$ (see Figure 3f). Densely-packed, unimodal (equigranular) anhedral dolomite crystals form hipidiotopic to xenotopic crystal mosaic fabric. Red colouration, observed in some of the microcracks, indicates calcitization.

\subsection{Physical and mechanical properties of the dolomites}

The values for apparent density, open porosity, water absorption and PLT strength of dolomites from the Dolje Quarry (D- samples), Ivanec Quarry (IB- samples) and Gradna Quarry (G- samples) were determined. All properties were determined on the same set of 26 samples. According to the results (see Table 1), there is a significant variation of physical and mechanical properties among the samples.

According to the water absorption curves (by mass. \%) related to time (in minutes), EDD samples from the Dolje Quarry (see Figure 4a) have a higher average value of water absorption (0.54 mass. \%) than LDD samples $(0.1$ mass. \%) from the same quarry. In the first 30 minutes of the testing procedure, EDD samples from the Dolje Quarry absorbed on average 0.39 mass. \%, which is $73 \%$ of the total absorbed water, while LDD samples absorbed 6.5 times less water. Among the dolomites from the Ivanec Quarry (see Figure 4b), EDD samples have the highest average water absorption value $(0.81$
Table 1: Measured values of the apparent density, open porosity, water absorption and strength by PLT for samples from the Dolje (D), Ivanec (IB) and Gradna (G) quarries. EDD - early-diagenetic dolomite, LDD - late-diagenetic dolomite, TD - "transitional" dolomite

\begin{tabular}{|l|c|c|c|c|}
\hline Sample & $\begin{array}{c}\text { Apparent } \\
\text { density } \\
\text { (g/cm }\end{array}$ & $\begin{array}{c}\text { Open } \\
\text { porosity } \\
\text { (vol. } \% \text { ) }\end{array}$ & $\begin{array}{c}\text { Water } \\
\text { absorption } \\
\text { (mass. \%) }\end{array}$ & $\begin{array}{c}\text { PLT } \\
\text { strength } \\
\text { (MPa) }\end{array}$ \\
\hline D-1 (EDD) & $\mathbf{2 . 7 7}$ & $\mathbf{1 . 7 7}$ & $\mathbf{0 . 6 4}$ & $\mathbf{2 . 4 3}$ \\
\hline D-2 (EDD) & $\mathbf{2 . 8 1}$ & $\mathbf{0 . 9 2}$ & $\mathbf{0 . 3 3}$ & $\mathbf{5 . 4 7}$ \\
\hline D-6-B (EDD) & $\mathbf{2 . 7 9}$ & $\mathbf{1 . 7 8}$ & $\mathbf{0 . 6 4}$ & $\mathbf{0 . 9 9}$ \\
\hline D-8 (EDD) & $\mathbf{2 . 6 7}$ & $\mathbf{1 . 4 9}$ & $\mathbf{0 . 5 6}$ & $\mathbf{5 . 8 1}$ \\
\hline Average value & $\mathbf{2 . 7 6}$ & $\mathbf{1 . 4 9}$ & $\mathbf{0 . 5 4}$ & $\mathbf{3 . 6 7}$ \\
\hline D-9-A (LDD) & $\mathbf{2 , 8 2}$ & $\mathbf{0 . 4 2}$ & $\mathbf{0 . 1 5}$ & $\mathbf{5 . 7 8}$ \\
\hline D-9-B (LDD) & $\mathbf{2 . 8 1}$ & $\mathbf{0 . 2 8}$ & $\mathbf{0 . 1}$ & $\mathbf{3 . 1 4}$ \\
\hline D-11 (LDD) & $\mathbf{2 . 8 2}$ & $\mathbf{0 . 3 7}$ & $\mathbf{0 . 1 3}$ & $\mathbf{1 . 6 2}$ \\
\hline D-13-A (LDD) & $\mathbf{2 . 8 4}$ & $\mathbf{0 . 2 3}$ & $\mathbf{0 . 0 8}$ & $\mathbf{6 . 1 9}$ \\
\hline D-14 (LDD) & $\mathbf{2 . 8 3}$ & $\mathbf{0 . 1 1}$ & $\mathbf{0 . 0 4}$ & $\mathbf{6 . 7 1}$ \\
\hline Average value & $\mathbf{2 . 8 2}$ & $\mathbf{0 . 2 8}$ & $\mathbf{0 . 1}$ & $\mathbf{4 . 6 8}$ \\
\hline IB-1-A (EDD) & $\mathbf{2 . 7 6}$ & $\mathbf{2 . 2 1}$ & $\mathbf{0 . 8}$ & $\mathbf{2 . 9 9}$ \\
\hline IB-1-B (EDD) & $\mathbf{2 . 7 6}$ & $\mathbf{2 . 1 8}$ & $\mathbf{0 . 7 9}$ & $\mathbf{3 . 4 7}$ \\
\hline IB-1-C (EDD) & $\mathbf{2 . 7 7}$ & $\mathbf{2 . 1 9}$ & $\mathbf{0 . 7 9}$ & $\mathbf{3 . 0 9}$ \\
\hline IB-2 (EDD) & $\mathbf{2 . 7 6}$ & $\mathbf{2 . 1 5}$ & $\mathbf{0 . 7 8}$ & $\mathbf{3 . 2}$ \\
\hline IB-3-A (EDD) & $\mathbf{2 . 7 7}$ & $\mathbf{1 . 5 2}$ & $\mathbf{0 . 5 5}$ & $\mathbf{1 . 1 4}$ \\
\hline IB-3-B (EDD) & $\mathbf{2 . 7 8}$ & $\mathbf{1 . 2 8}$ & $\mathbf{0 . 4 6}$ & $\mathbf{2 . 1 4}$ \\
\hline IB-5-A (EDD) & $\mathbf{2 . 7 1}$ & $\mathbf{4 . 0 1}$ & $\mathbf{1 . 4 8}$ & $\mathbf{1 . 5 9}$ \\
\hline Average value & $\mathbf{2 . 7 5}$ & $\mathbf{2 . 2 2}$ & $\mathbf{0 . 8}$ & $\mathbf{2 . 5 1}$ \\
\hline IB-10-C (TD) & $\mathbf{2 . 7 9}$ & $\mathbf{1 . 6 7}$ & $\mathbf{0 . 6}$ & $\mathbf{0 . 9 8}$ \\
\hline IB-10-D (TD) & $\mathbf{2 . 8 1}$ & $\mathbf{1 . 3 5}$ & $\mathbf{0 . 4 8}$ & $\mathbf{2 . 7 6}$ \\
\hline Average value & $\mathbf{2 . 8}$ & $\mathbf{1 . 5 1}$ & $\mathbf{0 . 5 4}$ & $\mathbf{1 . 8 7}$ \\
\hline IB-11-B (LDD) & $\mathbf{2 . 7 6}$ & $\mathbf{2 . 7 6}$ & $\mathbf{1}$ & $\mathbf{5 . 1 9}$ \\
\hline IB-12-C (LDD) & $\mathbf{2 . 8 2}$ & $\mathbf{1 . 0 1}$ & $\mathbf{0 . 3 6}$ & $\mathbf{1 . 1 5}$ \\
\hline IB-14-B (LDD) & $\mathbf{2 . 8 5}$ & $\mathbf{0 . 4 8}$ & $\mathbf{0 . 1 7}$ & $\mathbf{4 . 6 9}$ \\
\hline IB-14-C (LDD) & $\mathbf{2 . 8 3}$ & $\mathbf{0 . 8 8}$ & $\mathbf{0 . 3 1}$ & $\mathbf{1 . 3 1}$ \\
\hline Average value & $\mathbf{2 . 8 1}$ & $\mathbf{1 . 2 8}$ & $\mathbf{0 . 4 6}$ & $\mathbf{3 . 0 8}$ \\
\hline G-2 (LDD) & $\mathbf{2 . 8 2}$ & $\mathbf{0 . 5 1}$ & $\mathbf{0 . 1 8}$ & $\mathbf{1 . 4 1}$ \\
\hline G-4-A (LDD) & $\mathbf{2 . 7 8}$ & $\mathbf{0 . 9 7}$ & $\mathbf{0 . 3 5}$ & - \\
\hline G-5 (LDD) & $\mathbf{2 . 8}$ & $\mathbf{0 . 9 8}$ & $\mathbf{0 . 3 5}$ & - \\
\hline G-6 (LDD) & $\mathbf{2 . 7 4}$ & $\mathbf{0 . 8 7}$ & $\mathbf{0 . 3 2}$ & 3.34 \\
\hline Average value & $\mathbf{2 . 7 8}$ & $\mathbf{0 . 8 3}$ & $\mathbf{0 . 3}$ & $\mathbf{2 . 3 7}$ \\
\hline
\end{tabular}

mass. \%). As expected, TD samples from the Ivanec Quarry show values in between EDD and LDD values. All samples from the Ivanec Quarry quantitatively absorbed the most water in the first 24 hours of the testing procedure. The EDD samples had absorbed around $80 \%$ of the total absorbed water in the first 24 hours, while the LDD samples absorbed about $65 \%$. For LDD samples from the Gradna Quarry (see Figure 4c), a significant increase in water absorption was observed in the first 30 minutes of the testing (the average absorption in samples was 0.30 mass. $\%$, which is $81 \%$ of total water absorption value). Afterwards, the absorption of water slowly increased. 

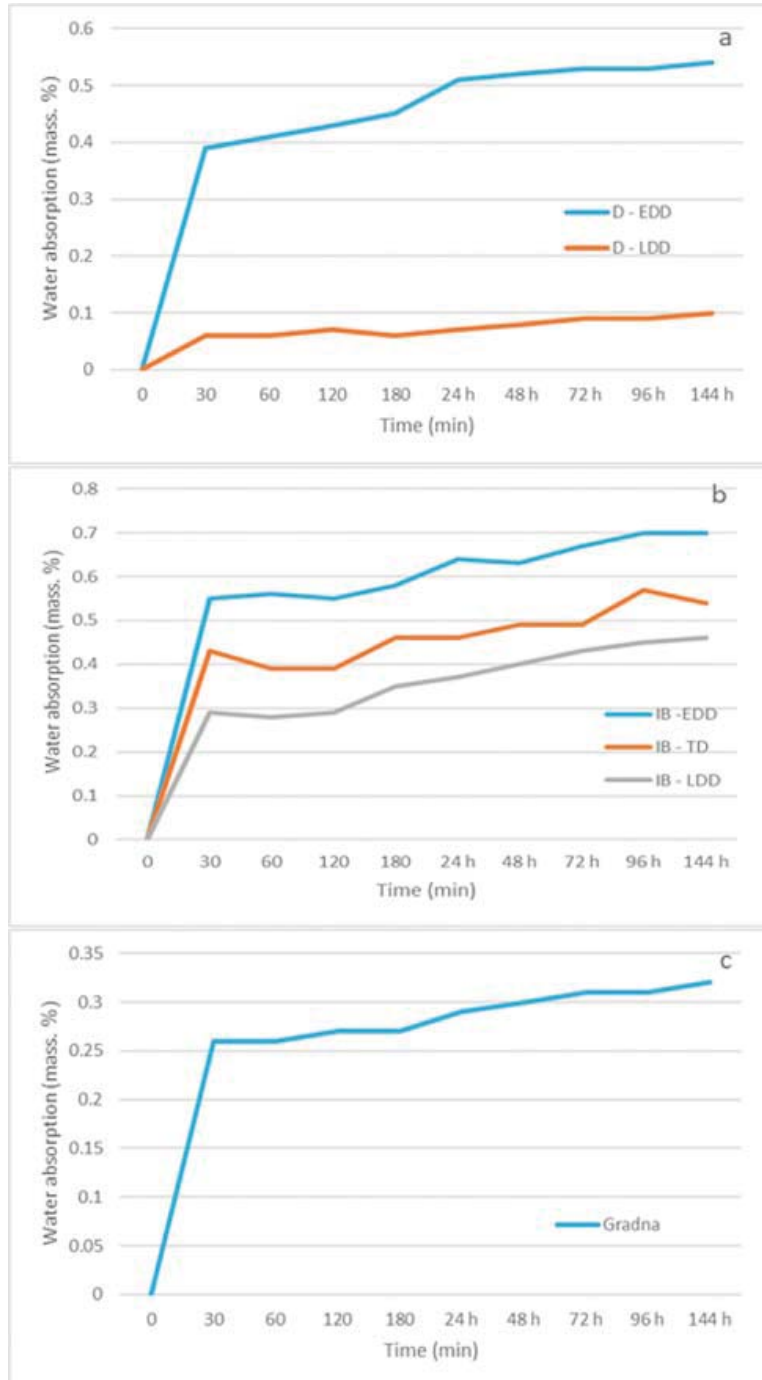

Figure 4: Graphical presentation of water absorption values (by mass. \%) related to time (in minutes) for dolomite samples taken from:

a) Dolje Quarry; b) Ivanec Quarry; c) Gradna Quarry

\section{Discussion}

The properties of the Dolje, Ivanec and Gradna quarries' dolomite samples, together with their comparison, are discussed in this section.

\subsection{Properties of the dolomite samples}

Micropetrographical characteristics and physical-mechanical properties were determined on the Upper Triassic dolomite samples, taken from three quarries: the Dolje, Ivanec and Gradna quarries. Samples from the Dolje Quarry were micropetrographically determined as early-diagenetic dolomite (EDD) and late-diagenetic dolomite (LDD). Samples from the Ivanec Quarry were determined as early-diagenetic dolomite (EDD), latediagenetic dolomite (LDD) and "transitional" dolomite
(TD). All samples from the Gradna Quarry were determined as late-diagenetic dolomite (LDD).

The main difference between the tested EDD and LDD samples is mostly in the sedimentary and diagenetic features present. The LDD samples differ from the EDD samples in anisotropy, such as stromatolitic lamination or lineation of the lamionid-fenestral fabric. Stromatolitic lamination is present in all determined EDD samples, as well as in TD, while LDD samples are not laminated. The EDD samples are also abundant in fenestral fabric, while the LDD samples for the most part do not contain fenestrae. Furthermore, EDD samples are mainly more dolomicritic, while in the LDD samples, dolomicrite is less evident. Cracks and microcracks are developed within all the described samples, but they are more abundant in EDD samples, especially in Ivanec EDD.

The LDD samples from the Ivanec and Dolje quarries have lower values of open porosity and water absorption, and higher values of apparent density, in comparison to EDD samples. Accordingly, the values of point load strength are reduced in EDD samples, in comparison to the LDD (see Table 1). These properties are mainly influenced by the presence or the absence of the main sedimentary and diagenetic features in these samples.

\subsubsection{Influence of the fenestral fabric}

The presence of the mainly laminoid-fenestral fabric type within the EDD samples increased their open porosity and water absorption values. The predominant laminoid-fenestral fabrics present in the described EDD samples are of LF-A subtype (according to Flügel, 2004; adopted from Tebbut et al., 1965), having subparallely distributed fenestral voids, mainly filled with the internal sediment and/or dolosparitic mosaic cement. Some of the voids are empty, and therefore significantly contributed to the increased open porosity and water absorption values, as well as to the reduced values of the apparent density and point load strength. Fenestral fabric is almost absent in LDD samples, and therefore has no effect on their properties. The LDD samples have higher values of the point load strength and apparent density, together with lower open porosity and water absorption values, when comparing with the EDD samples (see Table 1). Fenestral fabric is also determined within "transitional" (TD) dolomite from the Ivanec Quarry, and their values for open porosity, water absorption and apparent density are in between the values for EDD and LLD samples from the same quarry.

\subsubsection{Influence of lamination}

Lamination, as the significant anisotropic feature, also affected the strength of tested rocks, similarly as reported by Garcia Del Cura et al. (2012). Despite the fact that point load strength tests were made according to the standards, with the maximum pressure pointed perpendicularly to the lamination in EDD samples (expect- 
ed to be the strongest direction within the rock), their PLT values are still significantly lower than in LDD samples (see Table 1). Pronounced lamination contributes to the formation of inhomogeneous and low-cohesive rocks, which easily break along the laminae. The influence of the pronounced lamination in EDD samples on their open porosity and water absorption values cannot be directly related, according to the results of the performed tests. However, cyanobacterial stromatolitic lamination is closely related to the development of the previously described laminoid-fenestral fabric. Therefore, we can also indirectly attribute high values of open porosity and water absorption and low values of apparent density to the presence of lamination in EDD samples.

\subsubsection{Influence of cracks and microcracks}

All samples have stochastically distributed cracks and microcracks. The EDD samples from the Ivanec Quarry and LDD samples from the Gradna Quarry are the representative examples for the influence of crack and microcrack development on the physical-mechanical properties of dolomites. Dolomite, and subsequently calcite, crystallized within the cracks, indicating their sinsedimentary or early-diagenetic origin and time of filling in two phases, at least: early (dolomitic) and late (calcitic). Microcracks, determined both in the EDD and LDD samples, are mainly filled with calcite, indicating their late-diagenetic origin. The filling of the cracks occurred mainly due to calcitization in meteoric diagenetic environments. Numerous microcracks decreased the strength values and increased the water absorption values of dolomites, despite the fact that in most of the samples, microcracks were subsequently filled with dolomite and/or calcite crystals. The maximum PLT strength values were found in the LDD samples, dominantly influenced by the lack of cracks and microcracks, which also affects lower water absorption and open porosity values and higher values of apparent density. The formation of the abundant cracks in the Gradna Quarry is mainly caused by tectonics (faulting). The lowest values of PLT strength are found in the Gradna Quarry samples (LDD) and in the TD samples from the Ivanec Quarry, due to the presence of cracks and microcracks.

\subsubsection{Influence of the crystal size}

The majority of the analysed samples have a broad range of dolomite crystal sizes, except for the EDD samples from the Ivanec Quarry, which have equigranular (unimodal) dolomite crystals. Accordingly, these samples have high water absorption (average value 0.81 mass. \%) and open porosity (average value 2.22 vol. \%) values. The EDD samples with small-sized crystals do not have high strength values as expected, due to the negative effect of lamination and fenestral fabric on the strength. The LDD samples from the Dolje Quarry are predominantly fine-grained, but their crystal sizes range between 0.02 and $0.12 \mathrm{~mm}$, while the larger crystals fill the microcracks. This resulted in decreased open porosity and water absorption values, and increased values of strength by PLT (see Table 1). Moreover, small crystals fill the space between the large ones, contributing also to the water absorption decrease and porosity reduction.

\subsubsection{Influence of the diagenetic processes}

Diagenetic processes of dolomitization, cementation, recrystallization and calcitization, which are determined in the dolomites from the three quarries, have a significant influence on their physical and mechanical properties, similarly as other authors reported for carbonate rocks (Tomašić et al., 1992, 1997; Garcia Del Cura et al., 2005; Kaczmarek and Sibley, 2014; Barudžija et al., 2015; Pavičić et al., 2017). Dolomitization increased the open porosity in all samples, thus enhancing their water absorption capability. The development of cracks and microcracks already in the early-diagenetic stage, enhanced these properties. Additional cracks originated later, mainly due to tectonics, especially in the Gradna Quarry. Cementation of all these cracks and microcracks, mainly in the late-diagenetic stage, reduced the above mentioned properties. Some of the LDD samples are actually produced by recrystallization (i.e. Gradna Quarry LDD samples). Moreover, it seems that this secondary diagenetic process of recrystallization produced dolomites, for which exclusively we can be sure of their late-diagenetic origin (as suggested Grgasović (1998) for the Upper Triassic dolomites in the wide area of Žumberak). Calcitization developed in the late-diagenetic stage, mainly in and along the microcracks and additionally contributed to the decrease of the PLT strength values, especially in the Gradna Quarry samples.

\subsection{Comparison of the properties for dolomites from the Dolje, Ivanec and Gradna quarries}

The dolomite properties from all three of the investigated quarries were compared. Dolomites with high values for apparent density and strength by PLT, and with the low values for water absorption and open porosity, were considered to be of the best quality as an aggregate for construction applications.

Given that only one sample (see IB-5 (EDD) in Table 1) has the value of water absorption that exceeds 1 mass. $\%$. All other samples are predominantly categorized as rocks with low water absorption (according to the categories quoted by Crnković and Šarić, 2003). On the graphical presentation of water absorption related to time (see Figure 4), all samples from the Dolje, Ivanec and Gradna quarries showed significant water absorption within the first 30 minutes of the testing procedure. The reason is that during this time interval, water fills the pores and microcracks that are mutually connected. Stromatolitic lamination and the laminoid fenestral fab- 
ric in EDD samples enhance this property. In the later stage of the testing procedure, water fills the rest of the pores and microcracks, and in that period, the mass of the sample also increases, but not as much as in the first 30 minutes. The EDD samples absorbed much more water than the LDD samples, and TD samples are in between the EDD and LDD values.

The water absorption values were graphically compared with the strength values obtained by PLT (see Figure 5). Given the wide range of values, it was not possible to correlate the point load strength values with water absorption values. As well as with the open porosity evaluation, LDD dolomites from the Dolje Quarry proved to be of the best quality as an aggregate for construction applications, given that for the smallest water absorption, they have the highest values of PLT strength.

According to everything mentioned above, LDD dolomites from the Dolje Quarry have the best properties and thus the highest quality for construction applications. Due to their high apparent density values (average value is $2.82 \mathrm{~g} / \mathrm{cm}^{3}$ ), low open porosity (average value $0.28 \%$ ) and water absorption values (average value is 0.1 mass. \%) (see Table 1), they can be used in humid areas and in low-temperature areas as well, as they would most likely prove to be the most durable to the effect of freezing and crystallization of salts. Likewise, due to their high PLT strength (average value 4.69 MPa), which is comparable to the compressive strength (Bieniawski, 1975; Kahraman, 2001; Zhang, 2005), they are suitable for use in places that require stone resistant to mechanical wear.

Dolomites from the Dolje and Ivanec quarries are similar on a macro- and microscale, while Gradna dolomites differ. Unlike Dolje and Ivanec dolomites, Gradna dolomites have a typical late-diagenetic (recrystallized) structure, which affects the higher values of open porosity and water absorption, compared to LDD dolomites from the Dolje quarry. This is the consequence of the

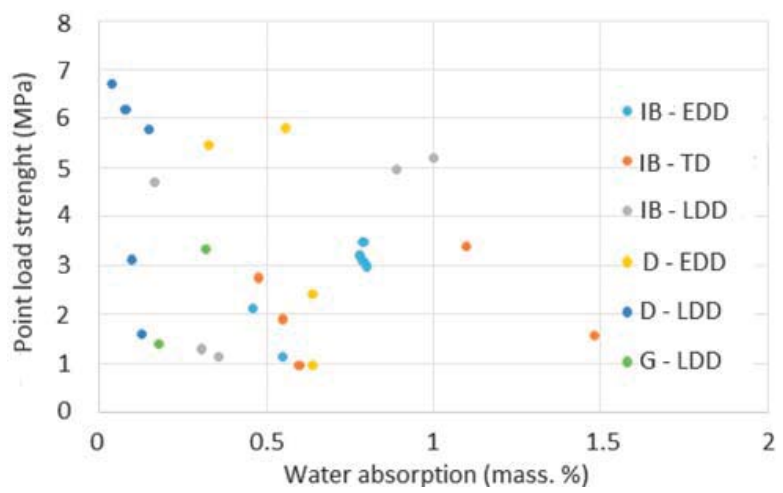

Figure 5: Graphical presentation of the water absorption values (by mass. \%) related to strength values by PLT (MPa), for the samples from: Ivanec (IB), Dolje (D) and Gradna (G).

EDD - early-diagenetic dolomite; TD - "transitional" dolomite; LDD - late-diagenetic dolomite. faulting tectonics, which affected Gradna dolomites and enabled the development of late-diagenetic processes.

\section{Conclusion}

Structure, sedimentary and diagenetic features and physical-mechanical properties have been determined and compared on the Upper Triassic dolomite samples taken from three quarries: Dolje, Ivanec and Gradna. The early-diagenetic dolomite (EDD) and late-diagenetic dolomite (LDD), are described. Additionally, the "transitional" dolomite (TD), having features of both main dolomites (EDD and LDD), is defined.

Prominent stromatolitic lamination and laminoid fenestral fabric in EDD samples, as the major anisotropy element, contributed to their low PLT strength values. These sedimentary and diagenetic features also contributed to increased water absorption and open porosity values. Besides that, cracks and microcracks, developed both in the early- and late-diagenetic stages, equally influenced the mentioned properties. The EDD samples are mainly small-sized and equigranular, which additionally contributed to their increased open porosity and water absorption values. Anisotropy is not evident in LDD samples, and therefore has no effect on their physical-mechanical properties. Apart from that, LDD dolomites from the Dolje and Ivanec quarries have less developed cracks and microcracks than LDD dolomites from the Gradna quarry, which resulted in unfavourable properties for Gradna samples. The defined "transitional" dolomite (TD) has values of open porosity, water absorption and apparent density between the values of EDD and LDD, which additionally supports the hypothesis that physical-mechanical properties were significantly influenced by sedimentary features.

Diagenetic processes have a significant influence on the physical and mechanical properties in all dolomite samples. Dolomitization increased the open porosity, thus enhancing their water absorption capability. Cementation of cracks and microcracks by dolomite and/or calcite, occurring mainly in the late-diagenetic stage, reduced these properties. According to the gained results, LDD samples from the Dolje Quarry have the highest apparent density and point load strength values, and the lowest water absorption and open porosity values as well. Therefore, the best for utilisation as crushed stone or aggregate, among all the tested dolomites, is LDD from the Dolje Quarry.

\section{Acknowledgements}

The authors would like to thank to Assoc. Prof. Petar Hrženjak, Head of the Geomechanics Laboratory at Faculty of Mining, Geology and Petroleum Engineering, for permission to use the laboratory and for help during the MS thesis preparation. We are also grateful to anonymous reviewers for suggesting improvements in the first version of the paper. 


\section{References}

Avanić, R., Grgasović, T., Pavelić, D., Šimunić, A. and Kovačić, M. (2000): Lithostratigraphic units of Lower Triassic in Žumberak and Samobor Hills;- Proceedings of the Second Croatian Geological Congress (eds. Vlahović, I. and Biondić, R.). Croatian Geol. Survey, 71-76, Zagreb. (in Croatian, with Abstract in English)

Babić, Lj. (1968): On the Triassic of Gorski Kotar and the neighbouring area.- Geološki vjesnik, 21, Zagreb, 11-18. (in Croatian, with Abstract in English)

Barudžija, U., Maričić, A. and Brčić, V. (2015): Influence of lithofacies and diagenetic processes on the physical and mechanical properties of carbonate rocks - case study from Sinawin-Sha'wa area, Libya.- Rudarsko-geološkonaftni zbornik (Mining-Geological-Petroleum Engineering Bulletin), 30, 29-48, Zagreb.

Barattolo, F. and Bigozzi, A. (1996): Dasycladaceans and Depositional Environments of the Upper Triassic-Liassic Carbonate Platform of the Gran Sasso (Central Apennines, Italy).- Facies, 35, 163-208, Erlangen.

Bieniawski, Z. T. (1975): The Point Load Test in Geotechnical Practice.- Engineering Geology, 9, 1-11.

Bosellini, A. (1965): Analisi petrografica della "Dolomia Prncipale" nel gruppo di Sella (Regione Dolomitica).- Mem. Geopaleont. d'Univ. Ferrara, 1/2, 49-109, Ferrara.

Bosellini, A. (1967): La tematica depositionale della Dolomia Principale (Dolomiti e Prealpi Venete).- Bolletino della Societa Geologica Italiana, 68/2, 133-168, Roma.

Bosellini, A. and Hardie, L.A. (1988): Facies e cicli della Dolomia Principale delle Alpi Venete.- Memoire della Societa Geologica Italiana, 30 (1985), 245-266, Roma.

Bukovac, J., Grgasović, T., Glovacki JerneJ, Ž., Jerinić, G., Galović, I. and Prtoljan, B. (1995): Lithostratigraphic subdivision of the Triassic dolomites in SW Žumberak within the Project of Basic Geological Mapping for Republic of Croatia 1:50.000.- Proceedings of the 1st Croatian Geol. Congress (eds. Vlahović, I. and Velić, I.). Croatian Geol. Survey, 137-142, Zagreb. (in Croatian, with Abstract in English)

Chilingar, G.V., Bissell, H.J. and Wolf, K.H. (1979): The Diagenesis of Carbonate sediments and Epigenesis (or Catagenesis) of Limestone. In: Larsen, G. and Chilingar, G.V. (eds.): Diagenesis in Sediments and Sedimentary Rocks. Developments in Sedimentology 25A.- Elsevier Sci. Publ., 249-424, New York.

Cirilli, S. and Tannoia, G. (1988): Studio stratigrafico e sedimentologico di un particolare sistema di margine e bacino nella Dolomia Principale dell'area di Menaggio (Lago di Como).- Memoire della Societa Geologica Italiana, 30 (1985), 313-326, Roma.

Climaco A., Boni, M., Iannace, A. and Zamparelli, V. (1997): Platform Margins, Microbial/Serpulids Bioconstructions and Slope-to-basin Sediments in the Upper Triassic of the "Verbicaro Unit" (Lucania and Calabria, Southern Italy).Facies, 11-64, Erlangen.

Crnković, B. and Šarić, LJ. (2003): Building with the natural stone. IGH, Zagreb, 380pp. (in Croatian)
De Zanche, V. (1990): A review of the Triassic carbonates of the Salerno province (Southern Italy): the Croci d'Acerno sequence.- Bolletino della Societa Geologica Italiana, 109, 187-217, Roma.

Evamy, B.D. and Shearman, D.J. (1962): The application of chemical staining techniques to the study of diagenesis in limestones.- Proceedings of the Geological Society of London, 1599, 102-103.

Flügel, E. (2004): Microfacies of Carbonate Rocks: Analysis, Interpretation and Application.- Springer-Verlag, 976pp, Heidelberg.

Fort, R., Bernabeu, A., Garcia Del Cura, M.A., Lopez De Azcona, M.C., Ordonez, S. and Mingarro, F. (2002): Novelda Stone: widely used within the Spanish architectural heritage.- Materiales de Construccion, 52, 266, 19-32.

Fruth, J. and Scherreiks, R. (1975): Facies and geochemical correlation in the Upper Hauptdolomit (Norian) of the eastern Lechtaler Alps.- Sedimentary Geology, 13, 27-45, Amsterdam.

Fruth, J. and Scherreiks, R. (1982): Hauptdolomit (Norian) Stratigraphy, paleogeography and diagenesis.- Sedimentary Geology, 32. 195-231, Amsterdam.

Fruth, J. and Scherreiks, R. (1984): Hauptdolomit - Sedimentary and paleogeographic models.- Geologische Rundschau, 73, 305-319, Stuttgart.

Fuček, L., Tišljar, J., Sokač, B., Prtoljan, B. and Oštrić, N. (1995): Stop 1: Upper Triassic dolomites in Podsused Quarry. In: Šikić, M. (ed.): Geologial Guide for Medvednica Mt. Croatian Geol. Institute and INA Petroleum Comp., 41-43, Zagreb. (in Croatian)

Garcia Del Cura, M.A., Benavente, D., Bernabeu, A., Fort, R., La Iglesia, A. and Ordonez, S. (2005): Use of the microcrystalline limestone as building material: the „Gris Pulpis“" case.- Materiales de Construccion, 55, 277, 5-23.

Garcia Del Cura, M.A., Benavente, D., Martinez-Martinez, J. and Cueto, N. (2012): Sedimentary structures and physical properties of travertine and carbonate tufa building stone.Construction and Building Materials, 28, 456-467.

Goldsmith, J. R. and Graf, D.L. (1958): Structural and compositional variations in some natural dolomites.- Chicago Journal of Geology, 66, 678-693.

Grgasović, T. (1997): Upper Triassic Biostratigraphy and Algae from Žumberak (Croatia).- Geologia Croatica, 50, 2; 201-214, Zagreb.

Grgasović, T. (1998): Stratigraphy of the Upper Triassic deposits of Žumberak, MSc Thesis, University of ZagrebFaculty of Science, 136pp, Zagreb. (in Croatian, with Abstract in English)

Gušić, I., Jelaska, V. and Nenadović, D. (1965): Prilog poznavanju vertikalne rasprostranjenosti trijaskih sferokodija (Beitrag zur Kenntniss der vertikalen Verbreitung der triadischen Sphaerocodien).- Geološki vjesnik, 18/1, 123-131, Zagreb. (in Croatian, with Abstract in German)

Herak, M. (1968): Noviji rezultati istraživanja osnovnih stratigrafskih jedinica u Žumberku (Neu Ergebnisse der Untersuchungen von stratigraphischen Haupteinheiten in Žumberak (W Kroatien).- Geološki vjesnik, 21, 111-116, Zagreb. (in Croatian, with Abstract in German) 
Herak, M. (2006): Medvednica Mt. - Misterious Zagreb Hill: Historical path toward the new geological cognitions. Special issue of the Croatian Acad. Sc. and Arts and Croatian Geol. Institute, 195pp, Zagreb. (in Croatian)

Jadoul, F. (1986): Stratigrafia e paleogeografia del Norico nelle Prealpi Begamasche occidentali.- Rivista Italiana de Paleontologia e Stratigrafia, 91/4, 479-512, Milano.

Jadoul, F. Berra, F. and Frisia, S. (1992): Statigraphic and paleogeographic evolution of a carbonate platform in an extensional tectonic regime: the example of the Dolomia Principale in Lombardy (Italy).- Rivista Italiana de Paleontologia e Stratigrafia, 98/1, 29-44, Milano.

Jadoul, F. and Gnaccolini, M. (1991): Sedimentazione ciclica nel Trias lombardo: osservazioni e prospettive.- Rivista Italiana de Paleontologia e Stratigrafia, 97/3-4, 307-328, Milano.

Kaczmarek, S.E. and Sibley, D.F. (2011): On the evolution of dolomite stoichiometry and cation order during high temperature synthesis experiments: an alternative model for the geochemical evolution of natural dolomites. Sedimentary Geology, 240, 30-40.

Kaczmarek, S.E. and Sibley, D.F. (2014): Direct physical evidence of dolomite recrystallization. Sedimentology, 61, 1862-1882.

Kahraman, S. (2001): Evaluation of simple methods for assessing the uniaxial compressive strength of rock.- International Journal of Rock Mechanics and Mining Sciences, 38, 981-994.

Müller-Jungbluth, W.-U. (1968): Sedimentary petrologic investigation of the Upper Triassic "Hauptdolomit" of the Lechtaler Alps, Tyrol, Austria. In: Müller, G. and Friedman, G.W. (eds.): Carbonate Sedimentology in Central Europe. Springer-Verlag, 228-239, Berlin.

Morse, J.W. (2005): Formation and Diagenesis of Carbonate Sediments. In: Mackenzie, F.T. (ed.): Sediments, Diagenesis and Sedimentary Rocks.- Treatise on Geochemistry, 7, Elsevier, 67-113, Amsterdam.

Morse, J.W. and Mackenzie, F.T. (1990): Geochemistry of Sedimentary Carbonates. Developments in Sedimentology, 48. Elsevier Sci. Publ., 707pp, Amsterdam.

Müller-Jungbluth, W.-U. (1970): Sedimentologische Untersuchungen des Hauptdolomits der östlichen Lechtaler Alpe, Tirol.- Festband Geol. Inst., 300-Jahr-Feier der Univ. Innsbruck, 255-308, Innsbruck.

Ogorelec, B. and Rothe, P. (1993): Mikrofazies, Diagenese und Geochemie des Dachsteinkalkes und Hauptdolomits in Süd-West-Slowenien (Mikrofazies, diageneza in geokemija dachsteinskega apnenca ter glavnega dolomita $\mathrm{v}$ jugozahodni Sloveniji).- Geologija, 35, 81-181, Ljubljana.

Pavičić, I., Dragičević, I., Vlahović, T. and Grgasović T. (2017): Fractal analysis of fracture systems in Upper Triassic Dolomites in Žumberak Mountain, Croatia.- Rudarskogeološko-naftni zbornik (Mining-Geological-Petroleum Engineering Bulletin), 32, 3, 1-13, Zagreb.

Purser, B.H., Brown, A. and Aissaoui, D.M. (1994): Nature, origins and evolution of porosity in dolomites. In: Purser, B.H.; Tucker, M.E. and Zenger D.H. (eds.): Dolomites - A Volume in Honour of Dolomieu. IAS Special Publication, 21; Cambridge.- Blackwell Sci. Publ., p. 283-308, Oxford.
Satterley, A.K. (1996): Cyclic carbonate sedimentation in the Upper Triassic Dachstein limestone, Austria: the role of patterns of sediment supply and tectonics in a platformreef-basin system.- Journal of Sedimentary Research, 66/2, 307-323, Tulsa.

Scholle, P.A. and Ulmer-Scholle, D.S. (2003): A Color Guide to the Petrography of Carbonate Rocks: Grains, Textures, Porosity, Diagenesis. AAPG Memoir, 77, 474pp, Tulsa.

Sibley, D.F. and Gregg, J.M. (1987): Classification of dolomite rock textures.- Journal of Sedimentary Petrology, 57, 967-975, Tulsa.

Smith, M.R. and Collis, L. (eds) (2001): Aggregates - Sand, gravel and crushed rock aggregates for construction purposes. Geol. Soc. Eng. Geol. (GSEG) Special Publication, 17, 339pp, London.

Šikić, K. and Basch, O. (1975): Geological events from Palaeozic to the Quaternary in the western part of Zagreb region. 2nd ann. meeting of the Section for Applied Geol., Geoph. and Geochem., Yug. Acad Sc. and Arts Zagreb, 68 - 86. (in Croatian, with Abstract in English)

Šikić, K., Basch, O. and Šimunić, A. (1977): Basic Geological Map of SFR Yugoslavia 1:100.000, Zagreb Sheet L38-80. Croatian Geol. Survey Zagreb, Federal Geol. Survey, Belgrade.

Šikić, K., Basch, O. and Šimunić, A (1979): Basic Geological Map of SFR Yugoslavia 1:100.000, Geology of Zagreb Sheet L38-80, 75pp. Croatian Geol. Survey Zagreb, Federal Geol. Survey, Belgrade. (in Croatian)

Tebbut, G.E., Conley, C.D. and Boyd, D.W. (1965): Lithogenesis of a carbonate rock fabric.- Contributions to Geology, $4,1-13$

Tišljar, J., Vlahović, I., Sremac, J., Velić, I., Veseli, V. and Stanković, D. (1991): Excursion A - Velebit Mt. PermianJurassic. Stop 3: Shallow-marine limestones and continental sediments from the Middle to Upper Triassic border. In: Vlahović, I. and Velić, I. (eds.): The second Int. Symposium on the Adriatic Carbonate Platform (Zadar, 1991), Excursion Guide-Book, 18-23, Zagreb.

Tišljar, J., Đokić, Z. and Ženko T. (1997): Influence of sedimentary environment on the technical properties of the Lower Cretaceous limestones from the Lakovići quarry in Istria (Croatia).- Rudarsko-geološko-naftni zbornik (Mining-Geological-Petroleum Engineering Bulletin), 9, 23-39, Zagreb.

Tomašić, I. and Peh, Z., (1992): Impact of the structural, petrographic and climatic factors on the slope stability in the open cast mine of Gradna.- Rudarsko-geološko-naftni zbornik (Mining-Geological-Petroleum Engineering Bulletin), 4, 67-74, Zagreb. (in Croatian, with Abstract in English)

Tomašić, I. and Ženko, T. (1993): The influence of structuraltextural and diagenetic factors on dimension stone porosities.- Rudarsko-geološko-naftni zbornik (Mining-Geological-Petroleum Engineering Bulletin), 5, 165-172, Zagreb. (in Croatian, with Abstract in English)

Tomašić, I., Salopek, B. and Krasić, D. (1990): The influence of diagenetic and tectonic processes in dolomites on the grinding.- Rudarsko-geološko-naftni zbornik (Mining- 
Geological-Petroleum Engineering Bulletin), 2, 47-51, Zagreb. (in Croatian, with Abstract in English)

Tomašić, I., Ženko, T. and Aljinović, S. (1992): Resistance of dolomite aggregates to freezing and abrasive impact strain.- Rudarsko-geološko-naftni zbornik (Mining-Geological-Petroleum Engineering Bulletin), 4, 119-126, Zagreb. (in Croatian, with Abstract in English)

Tomašić, I., Fistrić, M. and Vrkljan, M. (1997): Estimation of Resistance of Stone Aggregates to Recrushing.- Rudarskogeološko-naftni zbornik (Mining-Geological-Petroleum Engineering Bulletin), 9, 41-47, Zagreb.

Tomašić, I., Lukić, D., Peček, N. and Kršinić, A. (2011): Dynamics of capillary water absorption in natural stone.Bulletin of Engineering Geology and Environment, 70, 673-680.

Tucker, M.E. (1990): Dolomites and dolomitization models. In: Tucker, M.E. and Wright, V.P. (1990): Carbonate Sedimentology. Blackwell Sci. Publ., 365-400, Oxford.

Tucker, M.E. (2001): Sedimentary petrology: An Introduction to the Origin of Sedimentary Rocks. Blackwell Science Ltd, 262pp, Oxford.
Velić, I. and Sokač, B. (1982): New discoveries of the Lower and Middle Triassic in the western part of Kordun area (central Croatia).- Geološki vjesnik, 35, 47-57, Zagreb. (in Croatian, with Abstract in English)

Zenger, D.H., Dunham, J.B. and Ethington, R.L. (eds.) (1980): Concepts and Models of Dolomitization. SEPM Special Publication, 28, 320pp, Tulsa.

Zhang, L. (2005): Engineering Properties of Rocks, Vol. 4 (1st ed.). Elsevier Publ., 208pp, Amsterdam.

Testing methods:

HRN EN 1936: Natural stone test methods - Determination of real density, apparent density, and total and open porosity, Croatian Standards Institute, pp 9.

HRN EN 13755: Natural stone test methods - Determination of water absorption at atmospheric pressure, Croatian Standards Institute, pp 7.

ISRM (1985): Suggested method for determining point load strength. Int. Journal of Rock Mechanics and Mining Sciences and Geomechanical Abstracts. 22, pp. 51-60.

\section{SAŽETAK}

\section{Povezanost fizičko-mehaničkih svojstava dolomita sa sedimentnim i dijagenetskim značajkama - gornjotrijaski dolomiti Medvednice i Samoborskoga gorja, SZ Hrvatska}

U radu su opisane sedimentno-dijagenetske značajke nekoliko gornjotrijaskih dolomita i povezane su s njihovim fizičkomehaničkim svojstvima (prostorna masa, upijanje vode, otvorena poroznost i indeks čvrstoće mjeren opterećenjem u točki, PLT). Uzorci su uzeti iz triju kamenoloma: Ivanec i Dolje na Medvednici te Gradna u Samoborskome gorju. Uzorci iz kamenoloma Ivanec determinirani su kao kasnodijagenetski, ranodijagenetski i „prijelazni” dolomiti. Uzorci iz kamenoloma Dolje determinirani su kao ranodijagenetski i kasnodijagenetski, a uzorci iz kamenoloma Gradna kao kasnodijagenetski dolomiti. Najkvalitetnijim uzorcima za primjenu kao tehničko-građevni kamen odnosno agregat pokazali su se kasnodijagenetski dolomiti iz kamenoloma Dolje. Zbog svojih sedimentno-dijagenetskih značajki uzorci iz Dolja imaju najniže vrijednosti otvorene poroznosti i upijanja vode te ujedno visoke vrijednosti prostorne mase i PLT-a.

\section{Ključne riječi:}

dolomit, fizičko-mehanička svojstva, dijageneza, agregati, trijas, Hrvatska

\section{Authors Contribution}

All authors have equally contributed to research work and writing of the paper. Ana Maričić (Assistant Professor) is credited for the research hypothesis and development of the research as a mentor for MS thesis. She did the review of the literature and the interpretation of the physical-mechanical properties. Karlo Starčević (Master of Geology) researched this topic for his MS thesis and he made the testing of physical-mechanical properties as well the major part of micropetrographical analysis. He also produced all graphical presentations for the paper. Uroš Barudžija (Assistant Professor) contributed to the micropetrographical analysis and interpretation of the results. He mainly contributed to the discussion on the influence of sedimentary and diagenetic features. 